\section{S-1 肝细胞がんの初期侻}

国立がセンター研究所病理部 ○広㭗娧婎

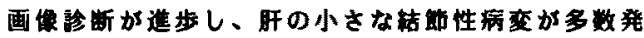

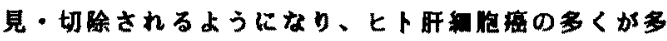

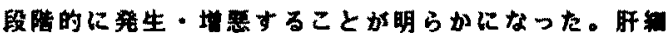

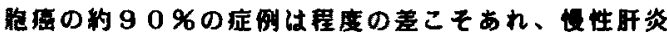
そして肝硣变を伴っている。この膘寒畈にモノクロー

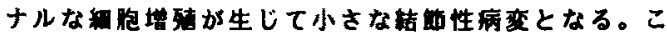

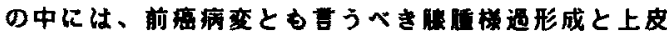

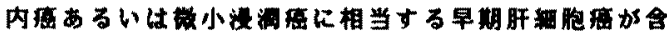
まれる。枯第の大きさか $1.5 \mathrm{~cm}$ 得を超えるようになる

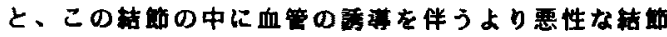
が结第内結第として共存していることが多い。この時 点で肝内枟移が起こるようでる。さらに瘦很胞の核

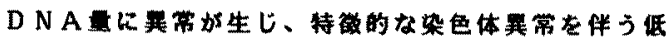
分化な癌に習墨して、肝外に転移するのである。我々

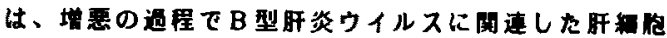

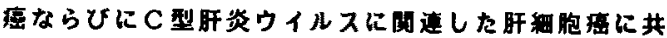
通に起こる染色体アレルの欠損を見いたししている。こ

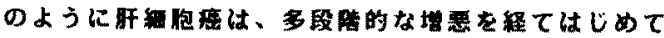

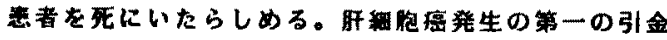

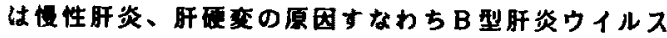
・C型肝炎ウイルスの感寂てあるが、その後の多段䧄

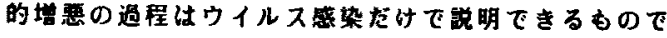
はなく、被の外因ならひに宿主要因の褲合によると 㤗えられる。

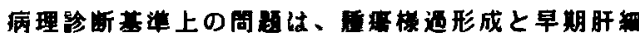
狍がんの填界をどこに置くかという点に较られた。頖 域として acinar structure、cord structure の改变 といった槽造型か見られること、周囲の 2 倍以上の

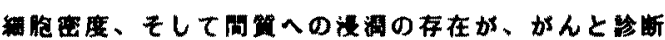
する重夏な战别点であることが共道の罚となりつつ ある。これらの病理䥻断と画澛そして医床経過がとの ように正理に対応するかについて、今徏多数症例ての

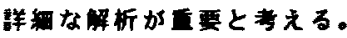

\section{S-2 早期肝細胞癌の病理組織学的ならびに 画像解析的検討 \\ 北里大学医学部病理 \\ ○本橋郁子、奥平雅彦}

〔目的〕我々は、肝細胞虚(以下肝渵)および肝癌境界 病変を含む各種肝智患の組織標本を、画像解析的手法 によって計測している。その目的は、細胞学的および 組織学的変化を数量化して表現することによって、高 分化型肝癌と境界病変との鈼別診断に客観的な指標を 設定することにある。本報告では、我々が早期肝癌病 変として注目している小型肝細胞集団の細胞学的およ び組䅧学的特徽を報告し、併せて早期肝溜の主体とな る高分化型肝癌、特に Edmondson- I 型(Ed- I )肝密 の画像解析による細胞学的および組織学的特徴を肝細 胞腺腫などの境界病変と対比して提示したい。

〔材料および方法〕検討应例は生検ならびに剖検され た、正常肝 8 例、非腫演性肝疾患80例、肝細胞腺腫 3 例、小型肝細胞集団 5 例、肝癌108例、(Ed- I 型38例、 Ed- II 型51例、Ed- III型12例、Ed- IV 型 5 例、肝芽腫 2 例)の計204例である。方法は、組織標本を500倍の 拡大率で写真掓影し、一定の大きさに引き伸ばして測 定に供した。。各例ともZeiss の画像解析装置(IBAS-1) を用いて核面積、N/C 比、細胞密度など11項目の测 定を行った。

〔結果】 I )小型肝細胞集団の画像解析による細胞学 的および組織学的特徴：小型肝細胞集団とは、早期肝 癁病変として我くが注目している病変であり、慢性活 動性肝资、腺腫様過形成を伴う肝硬変、肝細胞腺腫の 各 1 例、Ed- I 型肝癌 2 例に合併していた。小型肝細 胞集団の面像解析的特往は、1)核面積が小さい(正常 肝平均 $36.7 \mu \mathrm{m}^{2}$ に対し平均 $\left.\left.23.3 \mu \mathrm{m}^{2}\right) 。 2\right) \mathrm{N} / \mathrm{C}$ 比の上 昇(正常肝平均 0.17 に対し平均 0.31 )。3)細胞密度加高 い(正常肝平均25.4個/10,000 $\mu \mathrm{m}^{2}$ に対し平均66個)。4) 核の形状係数の低下(正常肝平均 0.95 に対し平均 $0.925)$ 。5)肝細胞索構成細胞数は、正常肝平均 $1.2 k$ 対して平均 2 である。その他の特徽として、带状分布 を示し結節を形成していない。Ｉ）早期肝瘦の主体と なる Ed-I型肝絽の画像解析による細胞学的および 組織学的特徵：Ed- I 型肝究の核面皘は平均 $39.4 \mu \mathrm{m}^{2}$ 、 $\mathrm{N} / \mathrm{C}$ 比は0.22、細胞密度は32.5個、核の形状係数は

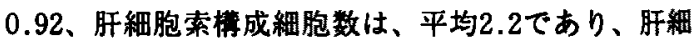
胞腺腫などの境界病変とは、核の形状係数、N/C比 および細胞密度などによって識別される。

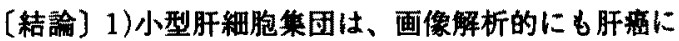
近似の值を示しており、早期肝癌の 1 つの実像であろ うと思われる。2)高分化型肝癌と肝細胞腺腫などの境 界病变の鏂別には、画像解析による検討結果が有用て あるが、細胞の脂肪化わよび淡明化、モザイク棈造の 存在、硝子体の出現などの組織所見も重要な指標とな る。 


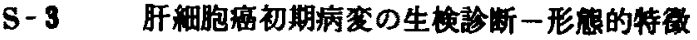
と組権化学的フプローテー

新渴大学第三内科

○市田隆文，山田慎二，

䀒細胞癌の $85 \%$ \%肝硬変を含し慢性肝疾患を併発し

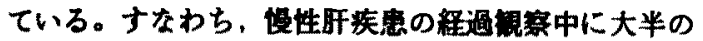

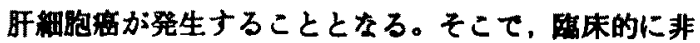

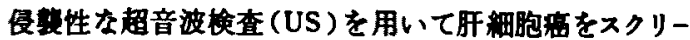
ニングし早期肝細胞㾔，主に緭小肝悹を見い出ナ努力 がなされている。その蔡，再生結節、腺嗹様過形成と 旰細胞瘦がそれぞれ低エコー，高エコ一領域と描出さ

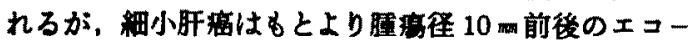

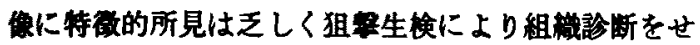
ざるを得ない状況てある。

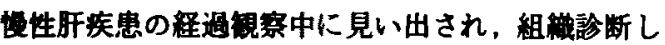
得る20例を対象とし，光影园察より初期病变とした11

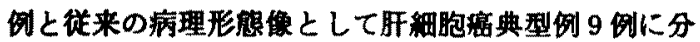
けた。初期病変の光影的特徽は以下の基苴とした。(1) 非腫部部に比して細胞密度が高い, (2)若干、胞体は好 藻基性てある，(3)核が類洞侧に倡在傾向にあり，(4)脂 肪变姓を伴い，(5)細胞索は厚く，(6)組維内に核分裂像

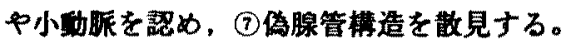

U S 誘这下狙目生検は絴经針を用いるため，得られ

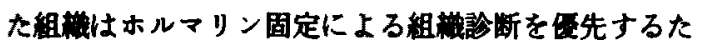
めP L P 固定などの特殊染色には不向をである。した がつてホルマリン固定材料を用いた組蟣化学を施し， H E 染色との連続切片による睍察をおこなった。瘦組

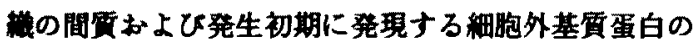
一てある oncofetal matrix proteinの tenascin と血 洞内皮紐胞形隹発現のマーカーてある第、因子関連抗 原（Fロ）を染色に供した。

Tenascinは癌組䋨周团の間兵に染色性を有し，血洞

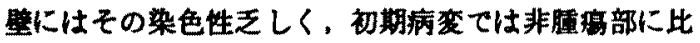
して血洞壁を中心とする染色性の乏しさが見い出され た。一方，F Vは典型例の 9 侧中 7 例に血洞内皮細胞 に強昜性を呈したが，初期病变群ては11例中10例にそ

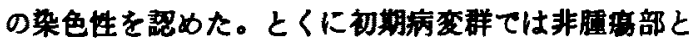
比教して，その差異が証められ，典型例ではより㤝く 染色された。

ホルマリン固定材料を用いた通常光䁰材料との連続

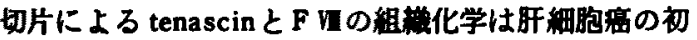
期病変の解析に役立つるのと考えられ今後，さらに症 例を增やして検討すべをと思われた。

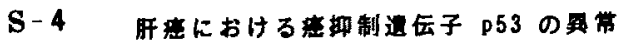

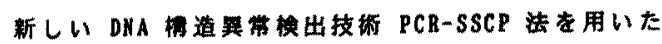
解析

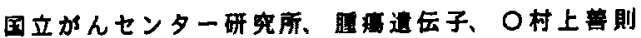

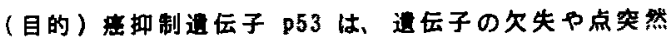
变算の異常により、ニつのアレルが共に不活化する ことによって、ヒトの转々のでその化に閏与して

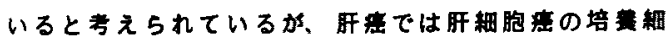

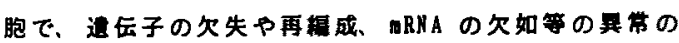

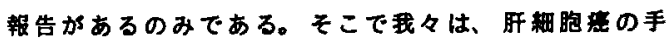

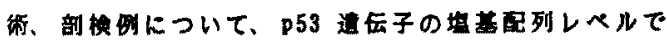

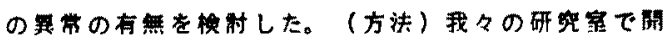

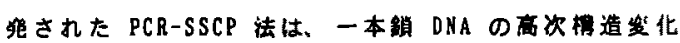

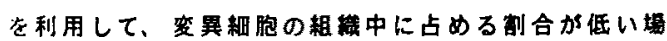
合においても、その紹臲の点突然变異等の在や、正 常アレルの欠失を、0.1ugの DNA から 12 時成以内に

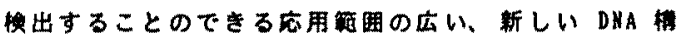
造異常换出法である。戴々は、国立がんセンター病院

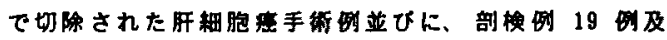
ひ同一者者の非部から抽出した DNAについて、この PCR-SSCP 法により、P53 运伝子のエクンン領域及ひ

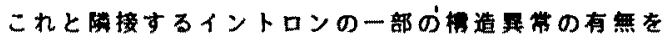

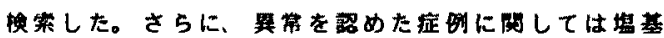

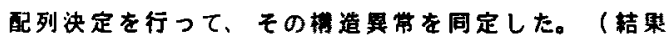
と考察)訮細胞在 19 列中 5 例(す心て乎術例)で p53选伝子のへテロ接合性の衰失を品め、この中の 3

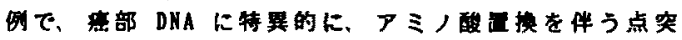
然变晎(コトン246 Bet(ATG)-Val (GTG),コドン244 GIY(GGC)-Ser(AGC)、コトン 110 Arg (CGT)-Cys(TGT)) を

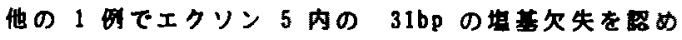

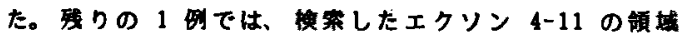
内には变異は畹められなかった。これらの变其の中の

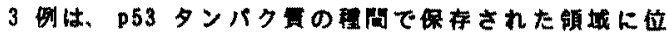

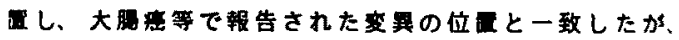

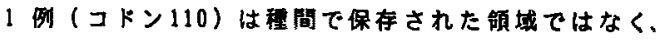
これまでに輁告のないエクンン4に存した。また变 界を现めた 5 列中 2 物では、同時に旰内に別の重戈

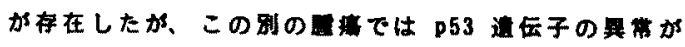

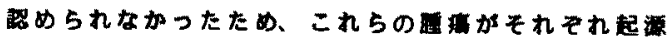
を異にする肝内多兔整である可性が高いと考えられ

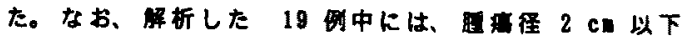

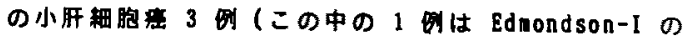

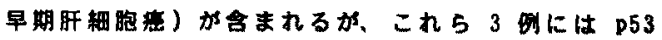

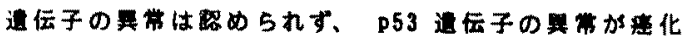

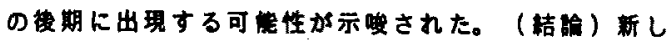

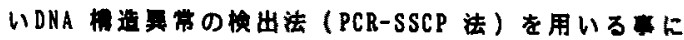

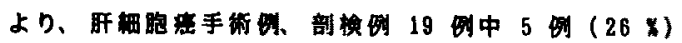

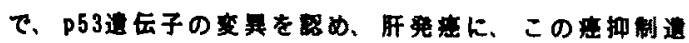
伝子の算需が的与していることを示した。 


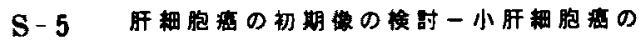 换出から確定彭断まで \\ 千菜大学第一内科杉溥信之、江原正明、}

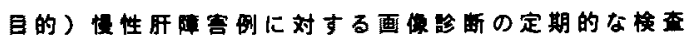

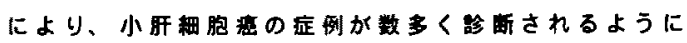

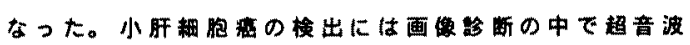
梌查が有用である。そこで小肝湅胞注の模出における 㫪音波梌查の役暳を明かにするために、自然経過例を 用いて四港产育速度を検封した。さらに、梌出された

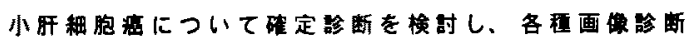

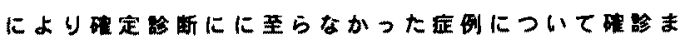
での柽週を明らかにした。

対象と方法)対象は干萧大学第一内科ならひに閶速施

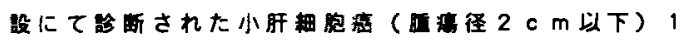

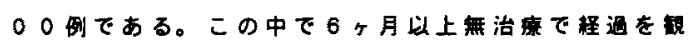

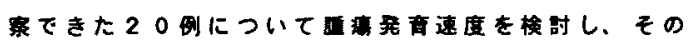

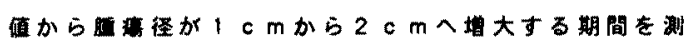

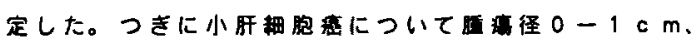
1ー2 c mにわけて超音波、 $x$ 袙 C T、MR 、、血管

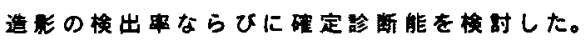

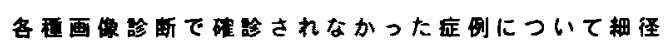
针による生梌を施行し模討した。

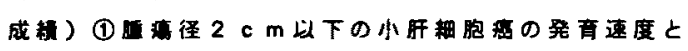
しての留容形倍加時间は1.4ヶ月から35，7ケ 月であった。径が $1 \mathrm{cmから} 2 \mathrm{~cm}$ 增大する期 間は最短 4 、2ケ月であった。(2)各琶画像部断による

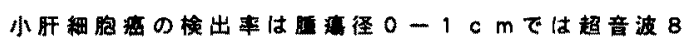

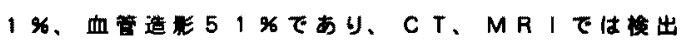

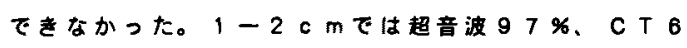
1\%、MR।68\%、血管造晊74\%であった。(3)

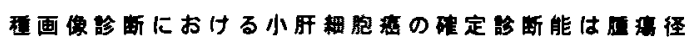

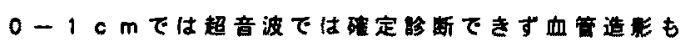

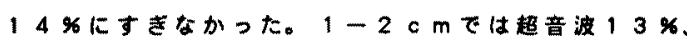
CT $29 \%$ 、MR I $35 \%$ ，血管造昣 $57 \%$ \%った。

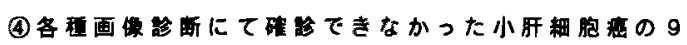

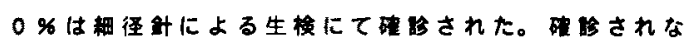

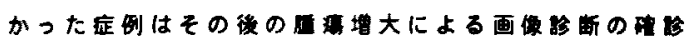

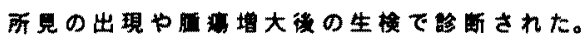

結語)

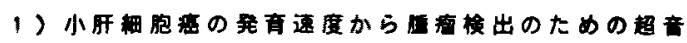

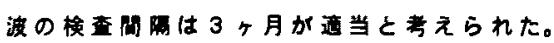

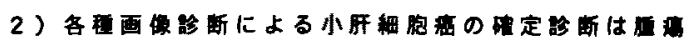

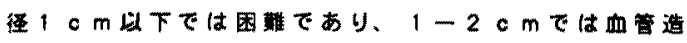

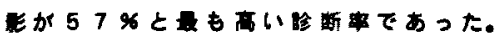

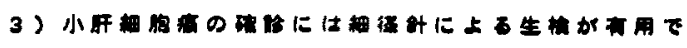
あった。
S-6 肝硬変経過中に出現与万小肝細胞㾇の画像的

特性之臨休像との関速につらて

虎の門病院消化器科

○池田健次・能田博光

肝硬变の臨床経過観察中に新をに出現した直径 $2 \mathrm{~cm}$ 以下の小肝程を、初期肝細胞病ととらえ、各種画像的 特性と臨床像につレて梌討した。

【対象、方法】対象怙、診断機器の発達した 1987 年 上り 1990 年まての間に、肝硬変の臨床経過中に新た に出現した最大腫場の直径 $2 \mathrm{~cm}$ 以下の肝細胞稻44例之 した。腫楊発見時、既炕多発性でっったのは13例てあ った。このらち、組学的に部断されたのは 25 例(外 科切除23例、細侱針生検のみ 2 例)て、、全例その後の 臨床経過または剖検て肝癌の磼定診断がなされている。 画像診断怯, DSA (Digital Subtraction Angiography）に上る血管造影を梅行し、22例飞炭酸ガス注入エ コー、17例K CT - P (CT - Portography) を施行し面 像上の特性と組絊学的・臨床的特徽との関連を検討し t。

\section{【成綪 】}

I. 血管造影上の「灌染結節」( hypervascular) と 「非灌染結節」( hypovascular)

1）「浱染結節」は32例、「非灌染結節」は12例炏見与

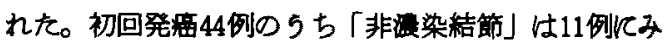
られたが、切除後再発癌 6 例ては「非港染結節」は1 例であった。2）初発時多発瘦であった13例ては、11

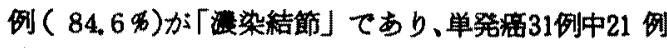
(67.7\%)K比し高染てあった。臨床的に初発巣と及 なされた結節が「非瀑染」のままて、「肝内転移巣」 のみが「灌染」となる应例すみられた。3）「浱染結 節」はEdmondson 分類 Iが 2 例、II が10例、Iが 2 例でったが、「非筑染結節」ては、Iが9例、【が 2 例と、前者ての分化度が低く、DSA ての腫場の造 影状態は組織学的分化度とは比例した。

I.「非瀑染結節」の訩断を㭪 万各種画像訅断

1)岸酸ガス動注を併用するアンギオエコー法を施行す ると「非港染結節」10例中 7 例淂性所見を認め、CT

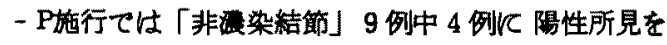
認めた。2)アンギオエコー・CT -Pは、一部の应例て 相補的て、两者を施行すれば、血篔造影て「非瀑染結 節」ですってい肝癌の補助部断となった。

【まとめ】1)肝癌の初期状䔮ては、血管造影上「流 染結節」と「非港染結節」に分けられ、前者の方汃分 化度が低く肝細胞富の典型的な組織像を呈する。小任 演ても発見時多発の例が少くなく、DSA は必須て、特 飞肝内転移の形の多発を多く発見でると考えられる。 2)「非筫染結節」の夏的診断には、アンギオエコー・ CT・Pの併用が相補的な価值をるち有意義てある。 


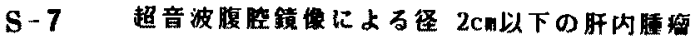

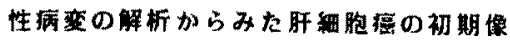
自治医科大学消化器内科" "、同病理 ${ }^{2 !}$

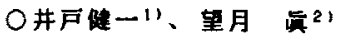

[目的]超音波腹㓐鏡の解像能は、得中超音波梌查のそ

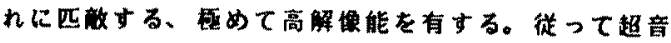

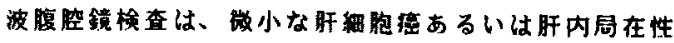

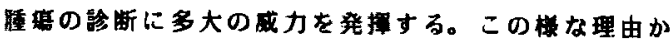
ら我々は肝细胞癌の症例はもちろん、肝硬変の应例も

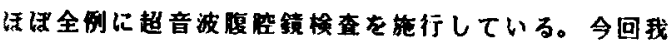

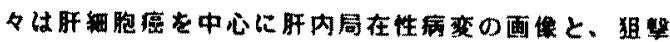

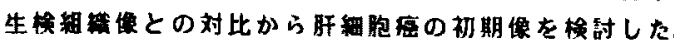
[対象および方法]超音波腹膯鏡下の腫湯生娭法の手技 が安定した 1987年10月より1990年5月までの期間に、

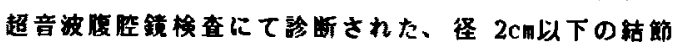

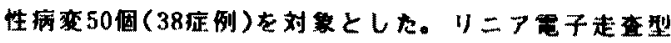

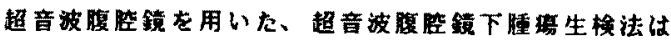
Gastroen-terol.Endosc.31:1528-1532,1989 に詳説し

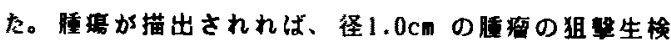
は培実に行える。使用した生换針は $21 \mathrm{Gあるいは} 22 \mathrm{G}$ のMajima needle である。結筩を病熊別に、单発、同

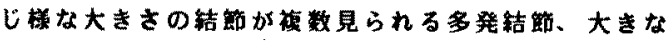
主結節かありその周囲あるいは他の区域に見られる副 結第の3類に分類した。备桔節の超音波画像は、高 エコー、低エコー、等エコーの3倕類に分類した。一

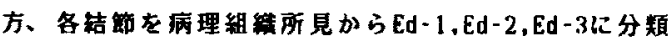

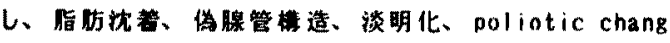
eの有製と程度について検討した。

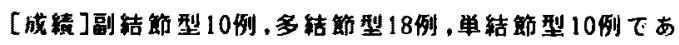
つた。超音波画像怡、佳 $2 \mathrm{~cm}$ 近いものは、従来より言

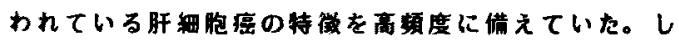

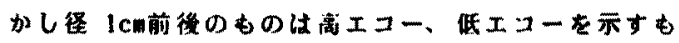
の、雨者涯在した。Ed分頻可能であった結第はEd-1 36.8\%、Ed-2 57.9\%、Ed-35.3\%でった。また肝緗胞 厔と診断不能な轺節は全体の40\%に見られ、このうち3 5れは凩汸沈着がみられた。

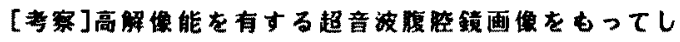

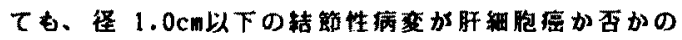

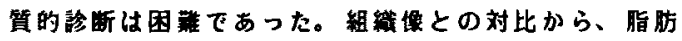
沈着の䧺られる桔節は高頻度に高エコーを示した。し かしこれらの結節には、脂肪沈普をともなう再生轺節 としか判断できない轺篇が多くみられた。しかす、こ

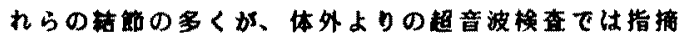

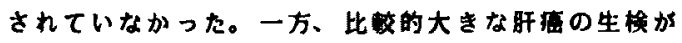
多かった徉来の肝生検では殆ど覞られなかったEd-1型

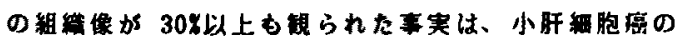

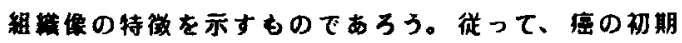

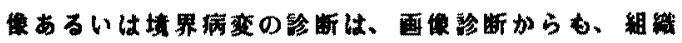

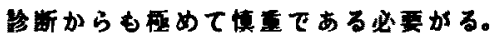

S-8 アンジェコー法による高分化型肝細胞毛 (Ed-I) D馀断

東京女子医科大学消化器病センター

○斎萠明子 中野雅行

肝症初期像の解明には，高分化型肝細胞窝 (Ed-I) に着目した检討が必須と考えられる。しかし，訮我の 画像診断法にさまざまて夫が行われている現在です。 Ed-Iの診断となるといまだ厚い壁に遮られている。 近年われわれは，アンシオエコー法に上り Ed-I が特 微的な所見として捉えられるととを見いだし，肝窟初 期の発青形態去につんての観察る可能となった。そ こて，Ed-I におけるアンシオエコー法の診断的意 につんて，切除標本に基づんた検討結果を述へる。

【対象と方法】

切除された $2 \mathrm{~cm}$ 以下の訮細胞盘58結節を検討対象之 した。病理組織所見に上bEd-Iの占め万割合に上っ

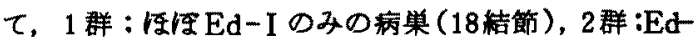
I のなが II IIIIVが島状に含まれる病柴 (13結節)， 3 群：主としてEd-IIIII加らなり，多くは辺緣の一部 にEd-I が王排されて認かられる病紧( 27 結節)に东け, アンシオエコー所見と対比した。

【成績と結果】

1) アンジォエコー所見はPositive enhancement (PE), Negative enhancement (NE), Non enhancement (Non E）に付けられた。対象結節のエンハンス像のハター ンをみると，1 群ではNE 72\%，PE 11\%であり,Non E が17\%認められた。2 群てはNE+PE 54\%，結節全体 がPE 23\%、NE 23\%ですり，3群はすべてPEを示し た。すなわち1群の多くはNEであり，2 群になると NE結節の内部に島状のPE部分が認められるよらにな り、 3 群では全例PEとなった。

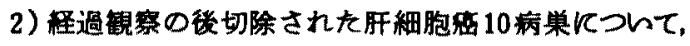
超音波像とアンジオェコー像の变化を涀察した。1， 2 群の 3 病巣はいずれる切除時までにほとんと增大を 認めなかった。3群のなかて 3 病巣は発見時から明ら かな增大を認めた。他の 4 病巣は 2 相性を呈し, 水平 相から急增相人の移行が招えられており，增大が明ら かになった时点て切除された病果てあった。発見時と 術前のアンシオエコー像を比較すると，1 群ではNon EからNon E，またはNEからNEへ，2 群ではNon E まをはNEから NE+PEへ，3群てはNonEまたはNE からPEへとい5变化がみられた。

【結棓】

$\mathrm{Ed} \mathrm{d}-\mathrm{I}$ 結節は, アンジオエコー法により NEとい5特 徽的所見として診断された。本法に上る経過観察によ り, $\mathrm{Ed}-\mathrm{I}$ 結節はその内部に $\mathrm{Ed}-I I \sim \mathrm{IV}$ 部分が出理 しその增大により結節としては増大するが，Ed-Iの 部分は辺相に王排され消失すると考えられた。 